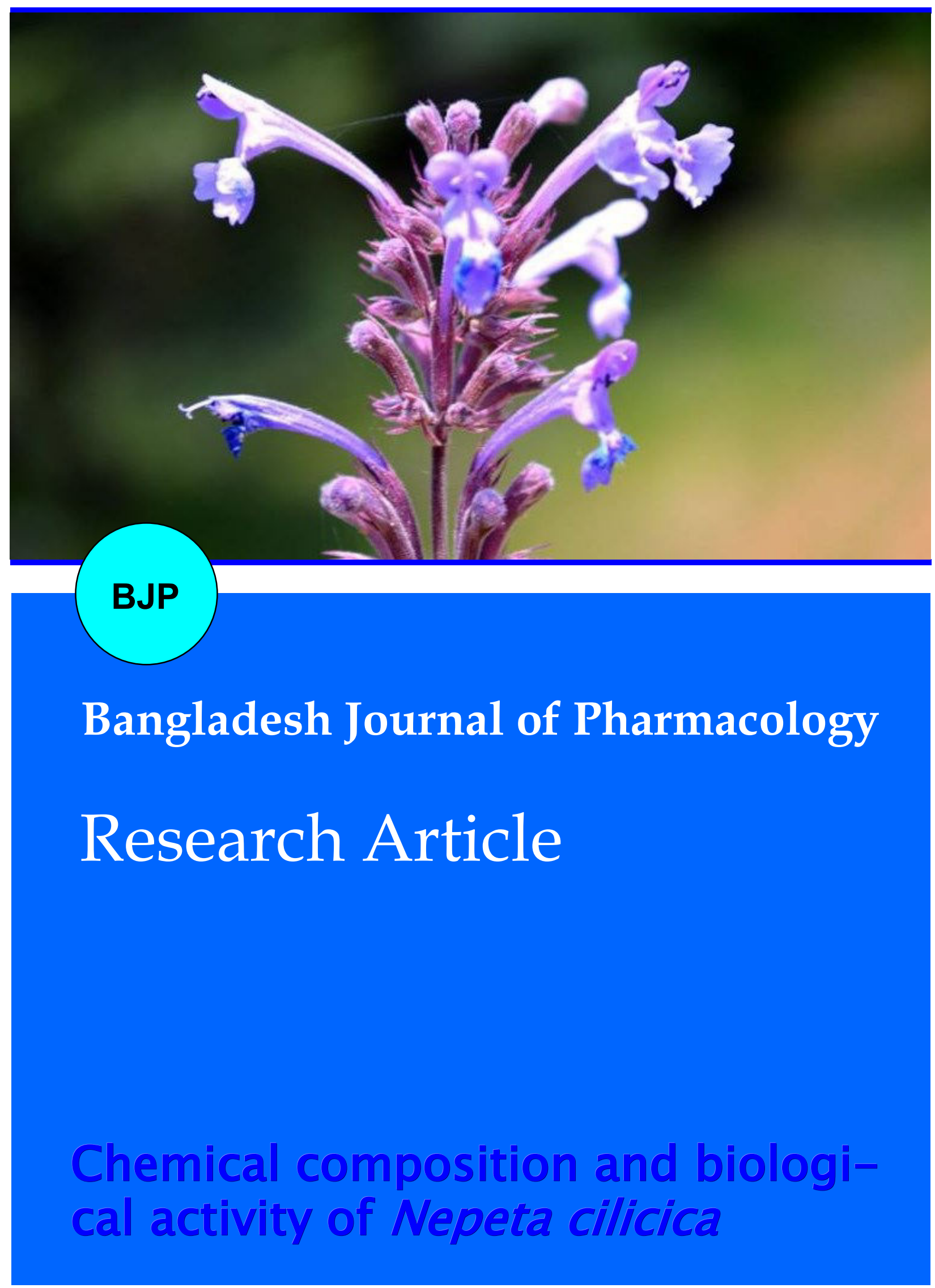


Abstracted/indexed in Academic Search Complete, Asia Journals Online, Bangladesh Journals Online, Biological Abstracts, BIOSIS Previews, CAB Abstracts, Current Abstracts, Directory of Open Access Journals, EMBASE/Excerpta Medica, Google Scholar, HINARI (WHO), International Pharmaceutical Abstracts, Open J-gate, Science Citation Index Expanded, SCOPUS and Social Sciences Citation Index;

ISSN: $1991-0088$

\title{
Chemical composition and biological activity of Nepeta cilicica
}

\author{
Gökalp İşcan'1, Fatih Göger¹, Betül Demirci' and Yavuz Bülent Köse² \\ ${ }^{1}$ Department of Pharmacognosy, Faculty of Pharmacy, Anadolu University, Eskisehir 26470, Turkey; ${ }^{2}$ Department of \\ Pharmaceutical Botany, Faculty of Pharmacy, Anadolu University, Eskisehir 26470, Turkey.
}

\begin{tabular}{|c|c|}
\hline \multicolumn{2}{|l|}{ Article Info } \\
\hline $\begin{array}{l}\text { Received: } \\
\text { Accepted: } \\
\text { Available Online: }\end{array}$ & $\begin{array}{r}30 \text { March } 2017 \\
16 \text { May } 2017 \\
20 \text { June } 2017\end{array}$ \\
\hline \multicolumn{2}{|c|}{ DOI: 10.3329/bjp.v12i2.32010 } \\
\hline \multicolumn{2}{|c|}{$\begin{array}{l}\text { Cite this article: } \\
\text { İşcan G, Göger F, Demirci B, Köse YB. } \\
\text { Chemical composition and biological } \\
\text { activity of Nepeta cilicica. Bangladesh J } \\
\text { Pharmacol. 2017; 12: 204-09. }\end{array}$} \\
\hline
\end{tabular}

\begin{abstract}
In the present study, aerial parts of Nepeta cilicica were hydro-distilled for the essential oil. Furthermore, air-dried plant materials were extracted with methanol. According to GC-MS results, 35 compounds were characterized in the oil (totally 92\%). Caryophyllene oxide, $\beta$-caryophyllene and spathulenol $(28.2,8.9$ and $4.2 \%)$ were found as main components of the oil. Sixteen compounds were detected by LC/MS, most of which were caffeoylquinic acid, luteolin and apigenin derivatives, in methanolic extract of the $N$. cilicica. Apart from DPPH radical scavenging activity, inhibitory effects on bacterial and yeast growth of essential oil and the methanolic extract were evaluated. Twenty-four different pathogenic bacterial and Candida strains were tested by M7-A7 and CLSI M27-A2 protocols respectively. The crude extract showed better inhibitory effects against bacteria strains than the essential oil. Both oil and the extract demonstrated strong inhibition on C. tropicalis at a concentration of $47.0 \mu \mathrm{g} / \mathrm{mL}$ (MIC).
\end{abstract}

\section{Introduction}

Nepeta cilicia is a perennial plant with stem size of 22$100 \mathrm{~cm}$. Some Nepeta species are used in the folk medicine for their therapeutic properties such as diaphoretic, diuretic, antiseptic, astringent, antiasthmatic, antitussive, anti-spasmodic, febrifuge, sedative, emmenagogue and stomachic. Flowering aerial parts of several Nepeta species are used as medicinal teas for their lemony mint odor and flavor (Duda et al., 2015; Shakeri et al., 2014; Formisano et al., 2013; Iscan et al., 2011; Skaltza et al., 2000).

Many compounds have been identified in Nepeta species such as monoterpenes, sesquiterpenes, flavonoids, phenolic acid, steroids and essential oils. The chemical composition of the essential oils derived from Nepeta can be of two categories. Nepetalactone containing and nepetalactoneless group that are generally rich in 1,8 -

A part of this study were presented at $11^{\text {th }}$ International Symposium on the Chemistry of Natural Compounds (SCNC 2015), on 1-4 October 2015, Antalya, Turkey. cineole (most abundant), pinenes, $\beta$-caryophyllene, $\beta$ farnesene, caryophyllene oxide, $\alpha$-citral and $\beta$ citronellol (Asgarpanah et al., 2014; Sharma and Cannoo, 2013; Skaltza et al., 2000). Nepetalactone isomers $4 \mathrm{a} a, 7 \mathrm{a}, 7 \mathrm{a} \alpha-$ nepetalactone, $\quad 4 a \beta, 7 a, 7 a \beta$ nepetalactone, $4 a \beta, 7 a, 7 a \alpha-n e p e t a l a c t o n e, 4 a \alpha, 7 a, 7 a \beta-$ nepetalactoneand $4 \mathrm{a \alpha}, 7 \beta, 7 \mathrm{a \alpha}$-nepetalactone are considered as biochemical indicator of the nepetalactone-rich group of Nepeta essential oils.

Biological efficacy is usually attributed to isoprene derivatives named nepetalactones especially found in the Nepeta oils (Kökdil et al., 1999; Başer et al., 2000; Skaltza et al., 2000; Nestorović et al., 2010). Even though two studies have been reported on the chemical composition of $N$. cilicica essential oil. There has not been any report about the chemical composition of the crude extract and antimicrobial activity of essential oil or the extract. According to previous studies sesquiterpenes ( $\beta$ -caryophyllene, spathulenol and $\beta$-caryophyllene oxide) and fatty acids have been determined as main compounds of N. cilicica essential oil (Formisano et al., 
2013; Kokdil et al., 1997).

In the present study, hydro-distilled essential oil and crude methanolic extracts of flowering aerial parts of $N$. cilicica were analyzed by chromato-spectral techniques. GC-MS with GC-FID and LC-MS systems were used for the determination of essential oil and the extract composition respectively. Both oil and extract were subjected to antimicrobial susceptibility assay against 24 pathogenic bacteria and Candida strains in comparison with the standard antimicrobial agents and also anti -oxidant assay for the first time.

\section{Materials and Methods}

\section{Plant material}

$N$. cilicica was collected from Anamur-Ermenek Road, İçel, Turkey on June 2014 in full flowering stage. Voucher specimen (ESSE: 14795) was kept in the Faculty of Pharmacy Herbarium, Anadolu University, Turkey.

\section{Isolation of essential oil}

The flowering aerial parts were air-dried at ambient temperature then subjected to a Clevenger-type apparatus for hydro-distillation for 3 hours according to European Pharmacopoeia 8.0, with a yield of $0.02 \%$ (on dried weight basis). The oil was dehydrated over sodium sulfate anhydrous and kept at $4^{\circ} \mathrm{C}$ until analysis.

\section{Preparation of the extract}

Extract of air-dried and grounded plant materials were prepared by the methanol (Merck) in an orbital shaker for 24 hours. After evaporation process at $40^{\circ} \mathrm{C}$, dried extract was kept in dark place at $4^{\circ} \mathrm{C}$ until analysis.

\section{GC-FID and GC-MS analysis}

The GC-FID and GC-MS analysis were carried out with innowax FSC columns $(60 \mathrm{~m} \times 0.25 \mathrm{~mm}, 0.25 \mathrm{~mm}$ film thickness) with helium $(0.8 \mathrm{~mL} / \mathrm{min})$ using Agilent 6890N GC and 5975 GC-MSD systems respectively. FID detector temperature was $300^{\circ} \mathrm{C}$. To obtain similar retention times between the GC-FID and GC-MS, synchronous automatic duplicated injection was performed using equal column by setting the same operational parameters. Relative percent of the detected compounds were calculated from the FID chromatograms.

\section{Identification of the compounds}

Characterization and identification of the $N$. cilicica essential oil components were fulfilled by comparison of their relative retention time with those of genuine samples or by comparison of their relative retention indices (RRI) to $n$-alkanes $\left(\mathrm{C}_{6}-\mathrm{C}_{16}\right)$. Software matching against commercial libraries (Wiley GC-MS and Mass Finder 3) (Koenig et al., 2004; McLafferty and Stauffer, 1989) and in-house "Başer Library of Essential Oil Constituents" created by genuine compounds and several constituents of the common essential oils, as well as MS data from previous works (ESO, 2000; Joulain and Koenig, 1998) were used for the identification.

\section{Phenolics analysed by LC-MS/MS method}

Applied Biosystems 3200 Q-Trap MS/MS system coupled to a Shimadzu 20A HPLC system was used in the negative ionization mode for the analyses of the phenolic compounds. Octadecyl silica gel analytical column (ODS $150 \times 4,6 \mathrm{~mm}$, i.d., $3 \mu \mathrm{m}$ particle sizes) for the separation operating at $40^{\circ} \mathrm{C}$ at a flow rate of $1 \mathrm{~mL} /$ min. HPLC elution was carried out using a gradient of the solvent mixture: $\mathrm{H}_{2} \mathrm{O}: \mathrm{CH}_{3} \mathrm{OH}: \mathrm{CH}_{2} \mathrm{O}_{2}$ (89:10:1, v/v/ v) (solvent $\mathrm{A}$ ) and $\mathrm{CH}_{3} \mathrm{OH}: \mathrm{H}_{2} \mathrm{O}: \mathrm{CH}_{2} \mathrm{O}_{2}(89: 10: 1, \mathrm{v} / \mathrm{v} / \mathrm{v})$ (solvent B). Solvent B composition was increased from 15 to $40 \%$ in $15 \mathrm{~min}, 40$ to $45 \%$ in $3 \mathrm{~min}$. It was held at $45 \%$ concentration for $12 \mathrm{~min}$. Then increased from 45 to $75 \%$ in $5 \mathrm{~min}$ and increased from 75 to $85 \%$ in $3 \mathrm{~min}$. In one minute, it was increased from 85 to $95 \%$ and it reached $100 \%$ concentration at $40 \mathrm{~min}$.

\section{Determination of total phenolic content}

Total phenol contents were calculated as gallic acid equivalents (GAE), which means mg gallic acid/g extract. Total phenolics in the oil and extract were determined using with previously described method (Singleton et al., 1999).

\section{DPPH radical scavenging activity}

The 1,1-diphenyl-2-picrylhydrazyl (DPPH•) scavenging activity determined according to the previous study of Kumarasamy et al. (2007). Serial dilutions of the stock solution of samples and stand arts were prepared as half concentrations of previous one. Equal amounts of $\mathrm{DPPH} \cdot$ reactive were added to the diluted solutions. After $30 \mathrm{~min}$ UV absorbance was recorded at $517 \mathrm{~nm}$.

\section{Antimicrobial susceptibility tests}

Antibacterial and anticandidal properties of the essential oil and methanol extract were evaluated by using partially modified CLSI microdilution broth methods (CLSI-M7-A7 and CLSI-M27-A2). Unlike the reference methods, the essential oil and methanolic extract were diluted between the concentrations of 5.8 to $6000 \mu \mathrm{g} / \mathrm{mL}$. Ampicillin (Merck), chloramphenicol (Merck), amphotericin B (Sigma-Aldrich) and ketoconazol (Sigma-Aldrich) were used as standard antimicrobial agents. Microorganisms were obtained from ATCC, NRRL and RSSK (Refik Saydam National Type Culture Collection, Turkey).

\section{Results}

\section{Phytochemical composition}

According to GC/MS results, 35 compounds representing $92 \%$ of the essential oil were characterized. The oil 
was constituted mainly by oxygenated sesquiterpenes $(47.5 \%)$, sesquiterpene hydrocarbons $(25.3 \%)$, alkanes $(10.2 \%)$, oxygenated monoterpenes (3.7\%), acycylicditerpene derivative phytol (2.9\%) and fatty acids $(2.3 \%)$. Caryophyllene oxide $(28.2 \%)$ and $\beta$-caryophyllene $(8.9 \%)$ were determined as main compounds. Monoterpenes were detected only trace amounts in the essential oil (Table I).

According to the LC-MS/MS analyses, 16 compounds (Figure 1) were determined in the methanol extract of $N$. cilicica. The main compounds of the extract were determined as 5-caffeoylquinic acid, luteolin glucoside, luteolin glucuronide, apigenin glucoside and apigenin glucuronide. Luteolin and apigenin were also determined as aglycons (Table II).

\section{Biological activity}

The extract demonstrated weak DPPH radical scavenging activity at the concentration of $0.31 \pm 0.05 \mathrm{mg} / \mathrm{mL}$ (Gallic acid was $0.0025 \pm 0.0002 \mathrm{mg} / \mathrm{mL}$ ). Total phenol content was determined as $53.17 \mathrm{mg} \mathrm{GAE} / \mathrm{g}$ extract.

According to antimicrobial assay results essential oil and methanol extract showed weak to strong antimicrobial effects against 24 different pathogenic Candida and Gram positive and negative bacterial strains. The essential oil demonstrated strong activity against food pathogens Gram positive Bacillus subtilis and Listeria monocytogenes at the concentrations of 94 and $187 \mu \mathrm{g} / \mathrm{mL}$ (MIC) respectively (Table III). The strain of ATCC-750 C. tropicalis was inhibited by the essential oil having a MIC value of $47 \mu \mathrm{g} / \mathrm{mL}$. The essential oil demonstrated moderate to weak inhibitory effects against all other tested pathogens between the concentrations of 3,000 to $375 \mu \mathrm{g} / \mathrm{mL}$ (MIC).

According to broth dilution tests, methanol extract obtained from flowering aerial parts of the N. cilicica, demonstrated better antimicrobial effects rather than the essential oil. The methanol extract strongly inhibited the growing of Proteus vulgaris, B. cereus, $B$. subtilis, Staphylococcus aureus and Listeria monocytogenes at the concentrations of 94,187, 94, 47 and $90 \mu \mathrm{g} / \mathrm{ml}$. The essential oil and methanol extract almost showed same effects against Candida strains. Similar to essential oil, C. tropicalis was inhibited by the methanol extract at the concentration of $47 \mu \mathrm{g} / \mathrm{mL}$ (Table IV).

\section{Discussion}

Essential oil composition of the Nepeta species has been varying according to the growing region, environmental conditions and soil type, which they are generally divided into two groups nepetalactone containing and nepetalactoneless as reported in

\section{Table I}

Composition of the essential oil of $N$. cilicia

\begin{tabular}{|c|c|c|c|c|}
\hline No & RRI & Compound & $\%$ & Method \\
\hline 1 & 1032 & a-Pinene & Trace & RRI, MS \\
\hline 2 & 1118 & $\beta$-Pinene & Trace & RRI, MS \\
\hline 3 & 1132 & Sabinene & Trace & RRI, MS \\
\hline 4 & 1255 & $\gamma$-Terpinene & Trace & RRI, MS \\
\hline 5 & 1280 & $p$-Cymene & Trace & RRI, MS \\
\hline 6 & 1466 & a-Cubebene & 0.6 & MS \\
\hline 7 & 1497 & a-Copaene & 2.7 & MS \\
\hline 8 & 1535 & $\beta$-Bourbonene & 1.5 & MS \\
\hline 9 & 1549 & $\beta$-Cubebene & 2.7 & MS \\
\hline 10 & 1611 & Terpinen-4-ol & 0.3 & RRI, MS \\
\hline 11 & 1612 & $\beta$-Caryophyllene & 8.9 & RRI, MS \\
\hline 12 & 1648 & Myrtenal & 0.1 & MS \\
\hline 13 & 1670 & trans-Pinocarveol & 0.1 & MS \\
\hline 14 & 1683 & trans-Verbenol & 1.5 & MS \\
\hline 15 & 1687 & a-Humulene & 1.3 & RRI, MS \\
\hline 16 & 1726 & Germacrene D & 3.0 & RRI, MS \\
\hline 17 & 1755 & Bicyclogermacrene & 1.5 & RRI, MS \\
\hline 18 & 1773 & a-Cadinene & 0.9 & MS \\
\hline 19 & 1776 & $\gamma$-Cadinene & 1.0 & MS \\
\hline 20 & 1804 & Myrtenol & 0.6 & MS \\
\hline 21 & 1849 & Calamenene & 1.2 & MS \\
\hline 22 & 1900 & epi-Cubebol & 2.6 & MS \\
\hline 23 & 2001 & Isocaryophyllene oxide & 3.8 & MS \\
\hline 24 & 2008 & Caryophyllene oxide & 28.2 & RRI, MS \\
\hline 25 & 2071 & Humulene epoxide-II & 3.5 & MS \\
\hline 26 & 2144 & Spathulenol & 4.2 & MS \\
\hline 27 & 2187 & T-Cadinol & 1.4 & MS \\
\hline 28 & 2239 & Carvacrol & 1.1 & RRI, MS \\
\hline 29 & 2289 & 4-Oxo-a-Ylangene & 1.7 & MS \\
\hline 30 & 2392 & $\begin{array}{l}\text { Caryophylla-2(12),6-dien- } \\
5 \beta \text {-ol (=Caryophyllenol II) }\end{array}$ & 2.1 & MS \\
\hline 31 & 2500 & Pentacosane & 2.5 & RRI, MS \\
\hline 32 & 2622 & Phytol & 2.9 & MS \\
\hline 32 & 2700 & Heptacosane & 4.5 & RRI, MS \\
\hline 34 & 2900 & Nonacosane & 3.2 & RRI, MS \\
\hline \multirow[t]{9}{*}{35} & 2931 & Hexadecanoic acid & 2.3 & RRI, MS \\
\hline & & $\begin{array}{l}\text { Monoterpene hydrocar- } \\
\text { bons }\end{array}$ & Trace & \\
\hline & & $\begin{array}{l}\text { Oxygenated monoter- } \\
\text { penes }\end{array}$ & 3.7 & \\
\hline & & $\begin{array}{l}\text { Sesquiterpene hydrocar- } \\
\text { bons }\end{array}$ & 25.3 & \\
\hline & & $\begin{array}{l}\text { Oxygenated Sesquiter- } \\
\text { penes }\end{array}$ & 47.5 & \\
\hline & & Fatty acids & 2.3 & \\
\hline & & Diterpenes & 2.9 & \\
\hline & & Alkanes & 10.2 & \\
\hline & & Total & 91.9 & \\
\hline
\end{tabular}

RRI relative retention indices; Trace $(<0.1 \%)$, \%calculated from FID data; Identification method based on the relative retention indices (RRI) of authentic compounds on the HP innowax column; MS, identified on the basis of computer matching of the mass spectra with those of the wiley and mass finder libraries and comparison with literature data 
Table II

\begin{tabular}{|c|c|c|c|}
\hline \multicolumn{4}{|c|}{$\begin{array}{c}\text { Phenolic compounds of the } N \text {. cilicica methanol } \\
\text { extract }\end{array}$} \\
\hline Rt & $\begin{array}{c}{[\mathrm{M}-\mathrm{H}]} \\
-m / z\end{array}$ & Fragments & Identified as \\
\hline 5.7 & 353 & 191,173 & 1-caffeoylquinic acid \\
\hline 7.5 & 315 & 153 & $\begin{array}{l}\text { Protocatechuic acid } \\
\text { hexoside }\end{array}$ \\
\hline 9.2 & 353 & $191,179,173$ & 5-Caffeoylquinic acid \\
\hline 11.5 & 337 & 191,173 & $\begin{array}{l}\text { 5-Coumaroylquinic } \\
\text { acid }\end{array}$ \\
\hline 13.0 & 448 & $287,151,135$ & Eriodictiol glucoside \\
\hline 13.2 & 447 & $285,151,133$ & Luteolin glucoside \\
\hline 13.6 & 461 & $357,285,151,133$ & Luteolin glucuronide \\
\hline 15.1 & 431 & $269,240,151,117$ & Apigenin glucoside \\
\hline 15.7 & 445 & $269,175,113$ & Apigenin glucuronide \\
\hline 16.3 & 359 & 197,161 & Rosmarinic acid \\
\hline 18.3 & 593 & $323,269,151,117$ & Apigenin derivative \\
\hline 18.9 & 487 & $269,217,113$ & Apigenin derivative \\
\hline 20.0 & 277 & $259,233,203$ & Unknown \\
\hline 21.0 & 285 & 133 & Luteolin \\
\hline 23.4 & 277 & 177,151 & Naringenin \\
\hline 23.9 & 269 & 151,117 & Apigenin \\
\hline
\end{tabular}

literature data. Apart from mono- and sesquiterpenes in essential oils, diterpenes, triterpenes, iridoids and their glucosides, were reported as major constituents of Nepeta species (Asgarpanah et al., 2014; Formisano et al., 2013; Sharma and Cannoo 2013; Başer, 2000; Skaltza et al., 2000).
Table III

\begin{tabular}{|c|c|c|c|c|c|}
\hline Bacteria & Sources & $\mathrm{Nc}^{1}$ & $\mathrm{Nc}^{2}$ & St-1 & St-2 \\
\hline $\begin{array}{l}\text { Pseudomonas } \\
\text { aeruginosa }\end{array}$ & $\begin{array}{l}\text { ATCC } \\
27853\end{array}$ & 3000 & 1500 & 16 & 4 \\
\hline $\begin{array}{l}\text { Enterobacter } \\
\text { aerogenes }\end{array}$ & NRRL 3567 & 3000 & 3000 & 8 & 1 \\
\hline Proteus vulgaris & $\begin{array}{l}\text { NRRL B- } \\
123\end{array}$ & 750 & 94 & 1 & 4 \\
\hline Bacillus cereus & $\begin{array}{l}\text { NRRL B- } \\
3711\end{array}$ & 375 & 187 & 2 & 4 \\
\hline Bacillus subtilis & $\begin{array}{l}\text { NRRL B- } \\
4378\end{array}$ & 94 & 94 & 1 & 1 \\
\hline $\begin{array}{l}\text { Serrati- } \\
\text { amarcescens }\end{array}$ & $\begin{array}{l}\text { NRRL B- } \\
2544\end{array}$ & 3000 & 3000 & 16 & 4 \\
\hline E. coli & ATCC 8739 & 3000 & 3000 & 2 & 1 \\
\hline $\begin{array}{l}\text { Salmonella } \\
\text { typhimurium }\end{array}$ & $\begin{array}{l}\text { ATCC } \\
14028\end{array}$ & 3000 & 3000 & 1 & 1 \\
\hline $\begin{array}{l}\text { Staphylococcus } \\
\text { aureus }\end{array}$ & ATCC43300 & 750 & 47 & 1 & 8 \\
\hline E. coli O157:H7 & RSSK 234 & 3000 & 3000 & 1 & 1 \\
\hline $\begin{array}{l}\text { Listeria mono- } \\
\text { cytogenes }\end{array}$ & $\begin{array}{l}\text { ATCC } \\
19111\end{array}$ & 187 & 90 & 1 & 2 \\
\hline S. epidermidis & $\begin{array}{l}\text { ATCC } \\
14990\end{array}$ & 750 & 187 & 1 & 1 \\
\hline
\end{tabular}

$\mathrm{Nc}^{1}$ : Essential oil of N. cilicica; $\mathrm{Nc}^{2}$ : Methanol extract of N. cilicica; St-1: Ampicillin; St-2: Chloramphenicol

In accordance with our results, sesquiterpenes were the

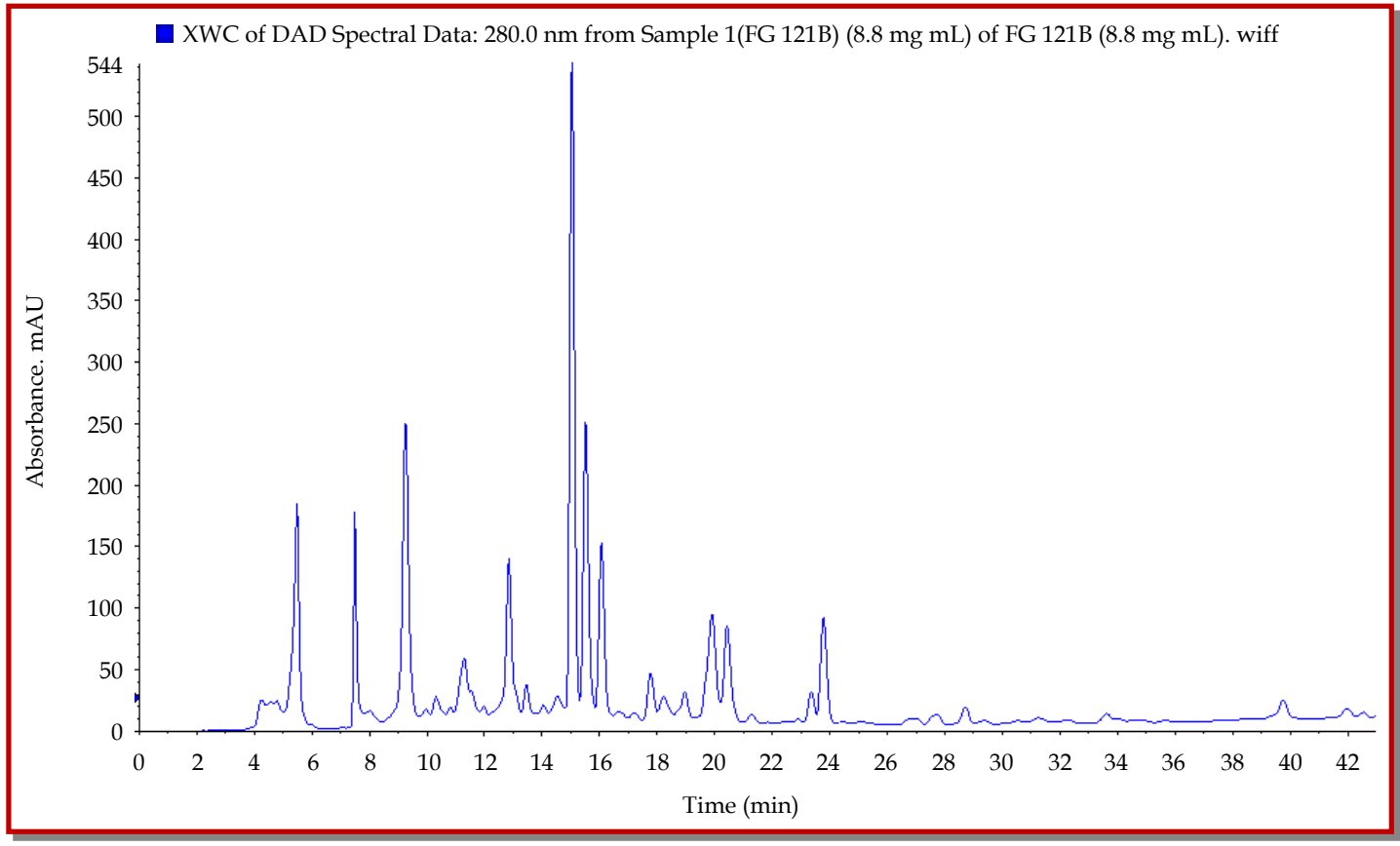

Figure 1: HPLC chromatogram of Nepeta cilicica methanol extract at $280 \mathrm{~nm}$ 


\begin{tabular}{|c|c|c|c|c|c|}
\hline \multicolumn{6}{|c|}{ Table IV } \\
\hline \multicolumn{6}{|c|}{$\begin{array}{c}\text { Anticandidal activity of } N \text {. cilicica essential oil and } \\
\text { methanol extract (MIC, } \mu \mathrm{g} / \mathrm{mL})\end{array}$} \\
\hline $\begin{array}{l}\text { Candida } \\
\text { strain }\end{array}$ & Sources & $\mathrm{Nc}^{1}$ & $\mathrm{Nc}^{2}$ & St-1 & St-2 \\
\hline C. albicans & ATCC 10231 & 375 & 750 & 0.5 & 0.1 \\
\hline C. utilis & NRRL Y-900 & 375 & 187 & 0.3 & 0.1 \\
\hline C. krusei & $\begin{array}{l}\text { NRRL Y- } \\
7179\end{array}$ & 750 & 750 & 0.5 & 0.3 \\
\hline $\begin{array}{l}\text { C. } \\
\text { zeylanoides }\end{array}$ & $\begin{array}{l}\text { NRRL Y- } \\
1774\end{array}$ & 750 & 750 & 0.5 & 0.1 \\
\hline $\begin{array}{l}\text { C. parapsilo- } \\
\text { sis }\end{array}$ & $\begin{array}{l}\text { NRRL Y- } \\
12696\end{array}$ & 375 & 187 & 0.5 & 0.1 \\
\hline C. glabrata & ATCC 2001 & 750 & 1500 & 1 & 0.1 \\
\hline C. glabrata & ATCC 66032 & 375 & 1500 & 1 & 0.1 \\
\hline C. tropicalis & ATCC 1369 & 750 & 750 & 0.5 & 0.1 \\
\hline C. albicans & $\begin{array}{l}\text { ATCC® } \\
24433\end{array}$ & 750 & 750 & 0.5 & 0.1 \\
\hline C. tropicalis & ATCC 750 & 47 & 47 & 1 & 0.1 \\
\hline $\begin{array}{l}\text { C. parapsilo- } \\
\text { sis }\end{array}$ & ATCC 22019 & 750 & 750 & 0.5 & 0.1 \\
\hline C. krusei & ATCC 6258 & 750 & 750 & 1 & 0.3 \\
\hline
\end{tabular}

$\mathrm{Nc}^{1}$ : Essential oilof $N$. cilicica; $\mathrm{Nc}^{2}$ : Methanol extract of $N$. cilicica; St-1: Amphotericin-B; St-2: Ketoconazole

major compounds $(73 \%)$ of $N$. cilicica oil. According to a few previous works on $N$. cilica essential oil, sesquiterpenes such as spathulenol (15.1\%), hexadecanoic acid $(14 \%)$ and $\gamma$-cadinene $(5.5 \%)$ were found as main compounds (Formisano et al., 2013). In the other study $\beta$-caryophyllene oxide (41\%), $\beta$-caryophyllene (15.7\%) and a-copaene $(2.7 \%)$ were reported as main components of the $N$. cilicica essential oil similar to our results (Kökdil et al., 1999).

To the best of our knowledge, this is the first study about phenolic content of $N$. cilicica. According to LCMS/MS analyses, 16 compounds were identified. The hydroxybenzoic acid derivatives (compounds 1-4) were identified using the identification keys of Clifford (Clifford et al. 2003). Caffeoylquinic acids are the ester of caffeic acid and (-)-quinic acid. Caffeoylquinic derivatives (chlorogenic acids) present characteristic molecular ion peak at $\mathrm{m} / \mathrm{z} 353[\mathrm{M}-\mathrm{H}]^{-}$. Compounds 1 and 3 were identified as 1-O-caffeoylquinic acid, 5-Ocaffeoylquinic acid respectively. Both of the compounds showed a base peak at $\mathrm{m} / \mathrm{z} 191$ ([quinic acid-H]-) discrimination were done according to the retention times where 1-O-caffeoylquinic acid elute earlier than 5O-caffeoylquinic acid. MS fragmentation of compound 4 showed a molecular ion peak at $\mathrm{m} / \mathrm{z} 337$ and a base peak ion at $\mathrm{m} / \mathrm{z}$ 191, being characterized as 5-pcoumaroylquinic acid. Compound 2 showed characteristic MS fragmentation of gentisic acid hexoside and protocatechuic acid hexoside with its pseudo molecular ion peak at $\mathrm{m} / \mathrm{z} 315$. Further fragmentation of $\mathrm{m} / \mathrm{z} 315$ resulted in an ion at $\mathrm{m} / \mathrm{z} 153$ because of the loss of a glucose moiety. Protocatechuic and gentisic acid differing only in their UV spectra characteristic (gentisic acid presents UV max at $330 \mathrm{~nm}$ while protocatechuic acid shows UV max at 260nm). Low UV intensity at 330 $\mathrm{nm}$ was let us to identify the compound 2 protocatechuic acid hexoside. Compound 14 showed pseudo molecular ion peak at m/z $285[\mathrm{M}-\mathrm{H}]-$ and identified as luteolin. Confirmation of compound 14 with authenthicluteolin standard. Compound 6 and 7 presented an aglycon ion as luteolin. Compound 6 showed a molecular ion peak at m/z $447[\mathrm{M}-\mathrm{H}]^{-}$and its MS/MS spectrum presented deprotonated luteolinaglycon ion at $\mathrm{m} / \mathrm{z} 285$ due to loss of a glucose unit (162 $\mathrm{amu}$ ). Compound 7 presented a pseudo molecular ion peak at $\mathrm{m} / \mathrm{z} 461$ which fragmented a product ion at $\mathrm{m} /$ z 285 by the loss of a glucuronic acid moiety (-176 amu). So, the compound 6 and 7 were identified as luteolin glucoside and luteolin glucuronide respectively. In a similar way, compound 16 identified as apigenin and compound 8 and compound 9 were identified as apigenin glucoside and apigenin glucuronide respectively. Compound 11 and compound 12 was not fully identified but determined as apigenin derivative. Compound 10 was determined as rosmarinic acid with its molecular ion peak at m/z 359 [M-H]- and further fragmentation was observed at $\mathrm{m} / \mathrm{z} 197$ due to the elimination of a caffeoyl moiety. The confirmation of compound 10 was done using the standard rosmarinic acid. Apigenin glucoside, apigenin glucuronide, luteolin glucoside and 5-caffeoylquinic acid were determined as the major compounds of the extract.

Total phenol content was determined as $53.17 \mathrm{mg}$ GAE/g extract. In different study Nepeta total phenol content was determined as 2.1-23.1 mg GAE/g extract (Kraujalis, et al. 2011). We calculated the highest total phenol content similar to previously calculated in $N$. catarica, N. bulgaricum, N. transcaucasia (Kraujalis et al. 2011) and N. praetervisa (Fareed et al. 2013).

The essential oil and the crude methanolic extract of $N$. cilicica were evaluated for their antibacterial and anticandidal properties for the first time here. The methanol extract found more active than essential oil against all tested bacteria species. Except $C$. tropicalis both essential oil and the methanol extract did not show remarkable effects pathogen Candida panel. According to all antibacterial results, both essential oil and the crude methanolic extract were slightly more active against Gram positive bacteria.

The study mainly focused on the bioactivity of the essential oil and total methanolic extract of $N$. cilicica used as food as well as medicine. Sesquiterpenes were found as major compounds of the essential oil where the caffeoylquinic acid, luteolin and apigenin derivatives were found in the extract. The essential oil showed 
strong inhibitory effects especially against food pathogen bacteria B. subtilis and Listeria monocytogenes. The total extract has stronger activity against all tested bacteria species. With the remarkable antimicrobial properties and phenolic content, $N$. cilicica total extract may be considered as a potential food preservation additive after further analysis.

\section{References}

Asgarpanah J, Sarabian S, Ziarati P. Essential oil of Nepeta genus (Lamiaceae) from Iran: A review. J Essent Oil Res. 2014; 26: 1-12.

Başer KHC, Kırımer N, Kürkçüoğlu M, Demirci B. Essential oils of Nepeta species growing in Turkey. Chem Nat Prod. 2000; 36: 356-59.

Clifford MN, Johnston KL, Knight S, Kuhnert N. Hierarchical scheme for LC-MSn identification of chlorogenic acids. J Agric Food Chem. 2003; 51: 2900-11.

CLSI M27-A2. Reference method for broth dilution antifungal susceptibility testing of yeasts. Approved standard. 2nd ed. 2002.

CLSI M7-A7. Methods for dilution antimicrobial susceptibility tests for bacteria that grow aerobically. Approved standard. 7th ed. 2006.

Duda SC, Mărghitaş LA, Dezmirean D, Duda M, Mărgăoan R, Bobiş $\mathrm{O}$. Changes in major bioactive compounds with antioxidant activity of Agastache foeniculum, Lavandula angustifolia, Melissa officinalis and Nepeta cataria: Effect of harvest time and plant species. Ind Crops Prod. 2015; 77: 499-507.

ESO 2000. The complete database of essential oils. Boelens Aroma Chemical Information Service, The Netherlands, 1999.

Fareed G, Afza N, Mali A, Fareed N, Lateef M, Iqbal L, Mughal UR. Phytochemical screening, total phenolic contents and biological evaluation of aerial parts of Nepeta praetervisa. J Chem Soc Pakistan. 2013; 35: 1364-68

Formisano C, Rigano D, Arnold NA, Piozzi F, Senatore F. GC and GC-MS analysis of the essential oil of Nepeta cilicica Boiss. exBenth. from Lebanon. Nat Prod Res. 2013; 27: 197581.

Hedge IC, Lamond JM. Nepeta L. Flora of Turkey and East Aegean Islands. Edinburgh, University Press, 1982, p 7.

Iscan G, Kose YB, Demirci B, Baser KHC. Anticandidal activity of the essential oil of Nepetatranscaucasica Grossh. Chem Biodivers. 2011; 8: 2144-48.

Joulain D, Koenig WA. The atlas of spectra data of sesquiterpene hydrocarbons, Hamburg, EB-Verlag, 1998.

Koenig WA, Joulain D, Hochmuth DH. Terpenoids and related constituents of essential oils. MassFinder 3, Hamburg, Germany, 2004.

KökdilG, Tanker M, Kurucu S, Topçu G. Essential oil analysis of Nepeta cilicia Boiss. Flavour Fragr J. 1997; 12: 99-101.

Kökdil G, Yalcin SM, Topçu G. Nepetalactones and other constituents of Nepetanuda ssp. albiflora. Turk J Chem. 1999; 23: 99-104.

Kordali S, Tazegül A, Cakir A. Phytotoxic effects of Nepeta meyeri Benth. extracts and essential oil on seed germinations and seedling growths of four weed species. Rec Nat Prod. 2015; 9: 404-18.

Kraujalis P, Venskutonis PR, Ragazinskiene O. Anti-oxidant activities and phenolic composition of extracts from Nepeta plant species. In: Proceedings of the 6th Baltic Conference on Food Science and Technology, 2011.

Kumarasamy Y, Byres M, Cox PJ, Jaspars M, Nahar L, Sarker SD. Screening seeds of some Scottish plants for free radical scavenging activity. Phytother Res. 2007; 7: 615-21.

McLafferty FW, Stauffer DB. The Wiley/NBS registry of mass spectral data. New York, J Wiley and Sons, 1989.

NestorovićJ, Mišić D, ŠilerB,Sokovic M, GlamoclijaJ, Cirić A,Maksimović V, Grubisić D. Nepetalactone content in shoot cultures of three endemic Nepeta species and the evaluation of their antimicrobial activity. Fitoterapia 2010; 81: 621-26.

Shakeri A, Khakdan F, Soheili V, Sahebkar A, Rassam G, Asili J. Chemical composition, antibacterial activity, and cytotoxicity of essential oil from Nepetau crainica L. spp. kopetdaghensis. Ind Crops Prod. 2014; 58: 315-21.

Sharma A, Cannoo DS. Phytochemical composition of essential oils isolated from different species of genus Nepeta of Labiatae family: A review. Pharmacophore 2013; 4: 181-21.

Singleton VL, Orthofer R, Lamuela-Ravento'ss RM. Analysis of total phenols and other oxidation substrates and antioxidants by means of folin-ciocalteu reagent. Vol. 299. San Diego, Academic Press, 1999.

Skaltsa HD, Lazari DM, Anargyros EL, Constantinidis T. Essential oil analysis of Nepeta argolica Bory \& Chaub. subsp. argolica (Lamiaceae) growing wild in Greece. Flavour Fragr J. 2000; 15: 96-99.

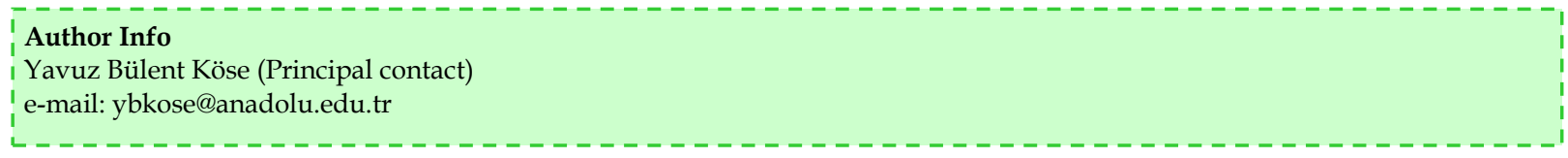




\section{Your feedback about this paper}

1. Number of times you have read this paper 0

2. Quality of paper Click

3. Your comments

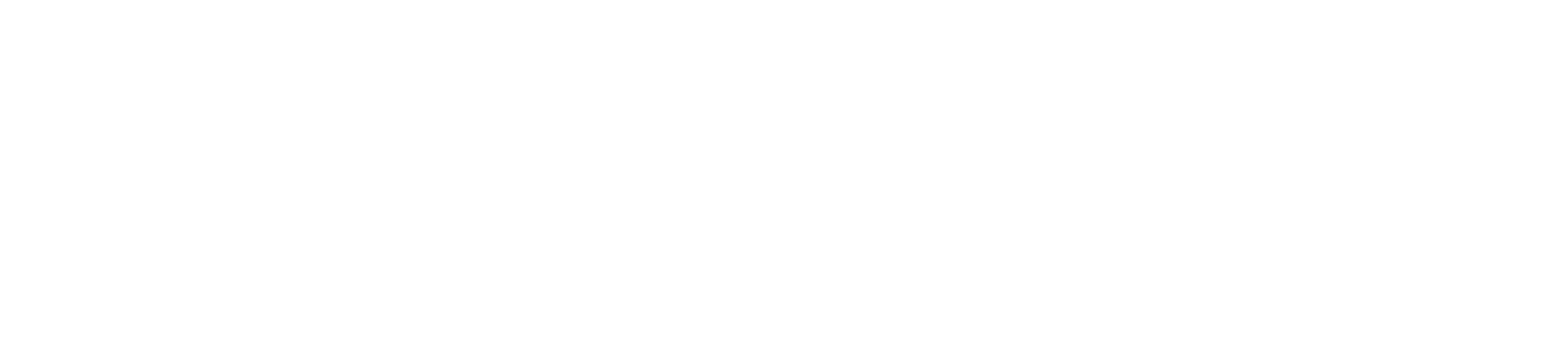

